\title{
Human-biometeorological conditions in the southern Baltic coast based on the universal thermal climate index (UTCI)
}

\author{
Leszek Kolendowicz $^{1} \cdot$ Marek Pólrolniczak $^{1} \cdot$ Katarzyna Szyga-Pluta $^{1} \cdot$ Ewa Bednorz $^{1}$
}

Received: 21 April 2017 / Accepted: 21 September 2017 /Published online: 28 October 2017

(C) The Author(s) 2017. This article is an open access publication

\begin{abstract}
The paper focuses on bioclimatic conditions in the southern part of the Baltic coast based on universal thermal climate index values. Taking into consideration the observational data from coastline stations as well as reanalysis data from the National Center for Environmental Prediction and National Center for Atmospheric Research (sea level pressure and the $500 \mathrm{hPa}$ geopotential height), the authors attempt to explain which of the synoptic situations are responsible for the occurrence of days with very strong and extreme cold or heat stress. The obtained results confirm that the extreme thermal heat and cold stress conditions are for the most part associated with high-pressure systems. The researched area is usually situated in the western or southern periphery of the anticyclones. The cold stress also occurs during the advection from west or northwest, caused by the direct influence of a lowpressure system whose center is situated over the North Sea, southern Scandinavia, or the southern Baltic Sea.
\end{abstract}

\section{Introduction}

Both regional climate and bioclimatic conditions are expected to change in the foreseeable future due to climate change (IPCC 2014). Despite global climate changes, the climate of seaside regions is largely shaped by the modifying effect of the sea, which reveals itself primarily as a decrease in diurnal and annual amplitudes. The seaside bioclimate stands out

Leszek Kolendowicz

leszko@amu.edu.pl

1 Department of Climatology, Institute of Physical Geography and Environmental Planning, Adam Mickiewicz University, Poznan, Poland from the other climates due to predominance of climate stimuli associated with a larger impact of cooling air value owing to the combined effect of low temperature, higher wind speed, and air humidity. Among many indices, UTCI (universal thermal climate index) is a modern tool for assessing thermophysiological conditions, because unlike others, it takes into account (among others) the thermoregulatory processes of the human body in a variety of ambient temperature conditions, thereby allowing for the ability to make an objectified evaluation of bioclimatic conditions (Błażejczyk et al. 2013b). UTCI was formulated as a result of international cooperation among various research institutions operating within the framework of European COST 730 and is actually recommended by the World Meteorological Organization (WMO) for operational use by meteorological services worldwide (Błażejczyk et al., 2012; Jendritzky et al. 2012; Bröde et al. 2012).

A comparison of various indices with UTCI has frequently been carried out (Błażejczyk et al. 2012; Bröde et al. 2013; Novak 2013, Błażejczyk et al. 2014a; Matzarakis et al. 2014; Światek 2014). The group of indices based on the human heat balance is very well correlated with UTCI. The most similar to UTCI values were found for indices PET (physiological equivalent temperature) (Mayer and Höppe 1987), PT (perceived temperature), SET (standard effective temperature), PST (physiological subjective temperature), PMV (predicted mean vote), and $\mathrm{PhS}$ (physiological strain). The $R^{2}$ coefficient of these indices is higher than $93 \%$. Less correlated with UTCI are indices based on relatively simply formulas (HI-heat index, AT - apparent temperature, Humidex, WBGT - wetbulb globe temperature, and WCT-wind child temperature). Although the values of PET and UTCI have not the same range (the lowest value of PET is about $62{ }^{\circ} \mathrm{C}$ and UTCI varied from -50 to $110^{\circ} \mathrm{C}$ ), the $R^{2}$ coefficients are 96.4 and slope of regression model is 0.84 . These results indicate that 
the values of PET and UTCI changed gradually over the whole temperature range (Błażejczyk et al. 2012).

UTCI is one of the indices which represents various weather and location conditions very well and is very sensitive to changes in temperature, humidity, solar radiation, and wind speed whereas the other, e.g., HI, Humidex, AT, PET, and PT, indices are more related to air temperature (Błażejczyk et al. 2012; Urban and Kyselý 2014).

Although UTCI is one of the best indices, it also has some weaknesses. One of them is a necessity of reduce wind speed to human-biometeorological reference height $(1.1 \mathrm{~m}$ a.g.l) which is done in UTCI procedure by use of a relatively simply approach. Next problem is estimation of Tmrt (mean radiation temperature) which is calculated on the base of solar radiation. However, it is worth to emphasize that the solar radiation measurements are relatively rare; Tmrt is calculated in BioKlima software package (Błażejczyk 2011) indirect with consideration of cloudiness and geographical position of measurement point.

The seasonal and regional variability of bioclimate has been evaluated by Błażejczyk et al. (2014a) using the example of selected European cities. The assessment of bioclimatic conditions within an area of a chosen country or urban areas has been the objective of different studies (Lindner 2011; Błażejczyk 2013; Mąkosza 2013; Milewski 2013; Błażejczyk et al. 2014b; Park et al. 2014). The thermal stress on the basis of UTCI values in relation to various pollutant concentrations (Nidzgorska-Lencewicz and Mąkosza 2013; Nidzgorska-Lencewicz 2015) and mortality (Błażejczyk et al. 2013a; Idzikowska 2011) in selected agglomerations was also considered. The index has been applied in certain studies concerning the best conditions for tourism and recreation (Lindner-Cendrowska 2013; Rutty and Scott 2014; Świątek 2014; Kažys and Malūnavičiūtè 2015; Ge et al. 2016). Given that up till now, not many studies have been devoted to various thermal stress occurrences in relation to atmospheric circulation factors, Nowosad et al. (2013) have tried to determine the correlation between UTCI and daily zonal and meridional circulation indices.

The aim of the study is a temporal and spatial analysis of human-biometeorological conditions in the southern Baltic coast based on UTCI, as the index more sensitive to changes in temperature, humidity, solar radiation, and wind speed whereas the other. The total impact on the observed humanbiometeorological conditions in the coastal zone has both sea surface, land area, and atmospheric circulation. By using observational data from the coastline stations as well as reanalysis data concerning the SLP (sea-level pressure) and geopotential high of $500 \mathrm{hPa}$, the authors attempt to explain which synoptic situations are conducive to the occurrence of days with very strong and extreme cold or heat stress. The used circulation analysis belongs to objective methods, contrary to subjective one based on calendars of synoptic situations, and allows to obtain average combine maps for distinguished synoptic situations.

The southern coast of the Baltic Sea has not been investigated in this regard yet, and such research could be important for example for the tourism and recreation sector in this region.

\section{Data and methods}

UTCI is defined as the equivalent ambient temperature of the reference environment that would elicit the same physiological response from a reference person as the actual environment. This means that the heat exchange between a person and the environment depends only on the air temperature, with other meteorological parameters at a constant level (Błażejczyk et al. 2012). UTCI values are a measure of the thermal stress in a person (Table 1). UTCI values between 18 and $26^{\circ} \mathrm{C}$ can comply closely with the "thermal comfort zone" definition (International Union of Physiological Sciences-Thermal Commission, 2003).

The area of interest concerns the southern part of the Baltic coast (Fig. 1). The meteorological data derived from the following stations for the period 1981-2014 were analyzed: Rostock (Lon. $12.080^{\circ}$, Lat. $54.180^{\circ}$, localization near the seashore next to promenade, altitude $4 \mathrm{~m}$ a.s.1.), Arkona (Lon. $13.437^{\circ}$, Lat. $54.678^{\circ}$, localization on country side, altitude $42 \mathrm{~m}$ a.s.l), Świnoujście (Lon. $14.242^{\circ}$ Lat. 53.923ㅇ, localization next to a gray dune at the seashore, outside in the city, altitude $5 \mathrm{~m}$ a.s.l.), Kołobrzeg (Lon. $15.579^{\circ}$, Lat. $54.182^{\circ}$, located near seashore among low urban development, altitude $10 \mathrm{~m}$ a.s.1.), Leba (Lon. $17.534^{\circ}$, Lat. $54.753^{\circ}$, located outside the city near the Lebsko like, altitude $10 \mathrm{~m}$ a.s.1.), and Hel (Lon. $18.811^{\circ}$, Lat. $54.603^{\circ}$, located out of the city, altitude $12 \mathrm{~m}$ a.s.l.). For Klaipeda (Lon. $21.091^{\circ}$, Lat. $55.731^{\circ}$, located near seashore among low urban development, altitude $7 \mathrm{~m}$ a.s.1.), the shorter period was used due to the lack of the data beginning from the year 2000 . The data for Polish stations were obtained from the Institute of Meteorology and Water Management National Research Institute (IMGW PIB), while others were from the database of the National Oceanic and Atmospheric Administration (NOAA USA). Despite that data originated from national weather service of Poland, Germany, and Lithuania and their location and measurement techniques fulfill WMO (World Meteorological Organization) requirements, authors additionally made the Alexanderson tests of data quality which confirmed their homogeneity (Guijarro 2016).

Based on measurements of air temperature, relative humidity, cloudiness, air pressure, and wind speed, the UTCI values were calculated using the BioKlima 2.6 software package (Błażejczyk 2011) for 12 UTC. Taken into consideration 
Table 1 UTCI assessment scale of thermal stress in man according Błażejczyk et al. (2010)

\begin{tabular}{|c|c|c|}
\hline $\begin{array}{l}\mathrm{UTCI}\left({ }^{\circ} \mathrm{C}\right) \\
\text { range }\end{array}$ & Stress category & Possible protection \\
\hline$\geq+46$ & Extreme heat stress & $\begin{array}{l}\text { Increase in rectal temperature (Tre) time gradient. Steep decrease in total net heat loss. Averaged sweat rate } \\
>650 \mathrm{~g} / \mathrm{h} \text {, steep increase. }\end{array}$ \\
\hline$\geq+38<+46$ & $\begin{array}{l}\text { Very strong heat } \\
\text { stress }\end{array}$ & Temporary body cooling and drinking $>0.5 \mathrm{l} / \mathrm{h}$ necessary. No physical activity. \\
\hline$\geq+32<+38$ & Strong heat stress & Temporary use of air condition or shaded places necessary. Drinking $>0.51 / \mathrm{h}$. Reduce physical activity. \\
\hline$\geq+26<+32$ & $\begin{array}{l}\text { Moderate heat } \\
\text { stress }\end{array}$ & Drinking $>0.25 \mathrm{l} / \mathrm{h}$. \\
\hline$\geq+9<+26$ & No thermal stress & Physiological thermoregulation sufficient to keep thermal comfort. \\
\hline$\geq 0<+9$ & Slight cold stress & Use gloves and hat. \\
\hline$\geq-13<0$ & $\begin{array}{l}\text { Moderate cold } \\
\text { stress }\end{array}$ & Intensify activity and protect face and extremities against cooling. \\
\hline$\geq-27<-13$ & Strong cold stress & Intensify activity and protect face and extremities against cooling. Use warmer clothing. \\
\hline$\geq-40<-27$ & $\begin{array}{l}\text { Very strong cold } \\
\text { stress }\end{array}$ & $\begin{array}{l}\text { Intensify activity and protect face and extremities against cooling. Use warmer clothing. Reduce outdoor exposure } \\
\text { time. }\end{array}$ \\
\hline$<-40$ & Extreme cold stress & Stay at home. If outdoor exposure is necessary use heavy and wind protected clothing. \\
\hline
\end{tabular}

human daily activity, the noon hours are the most representative period of the day (Kozłowska-Szczęsna et al. 2004).

As a first result of the research, the annual course of the UTCI for all chosen stations was shown. For instance, to arrive at UTCI values for $12 \mathrm{UTC}$, the frequency of days according to stress categories and annual trends in the number of days for the period 1981-2014 was analyzed.

The relatively small distance between the chosen stations accounts for the great similarities in the patterns of circulation types obtained from analysis of the impact on the value of UTCI. In the initial phase of this part of the study, a separate analysis of synoptic conditions for each station was carried out. In many cases, the results were virtually identical. For this reason, it seemed reasonable to consider the influence of atmospheric circulation on UTCI after the station grouping. Therefore, using the hierarchical grouping of Ward's method (1963) (Wilks 2006) and taking into consideration the mean monthly UTCI values for the period 1981-2014, all stations and months were grouped. By describing the synoptic situation characteristic of days with extreme UTCI values, three groups of weather stations were distinguished. Group 1 comprises only one station (Arkona). Group 2 comprises two

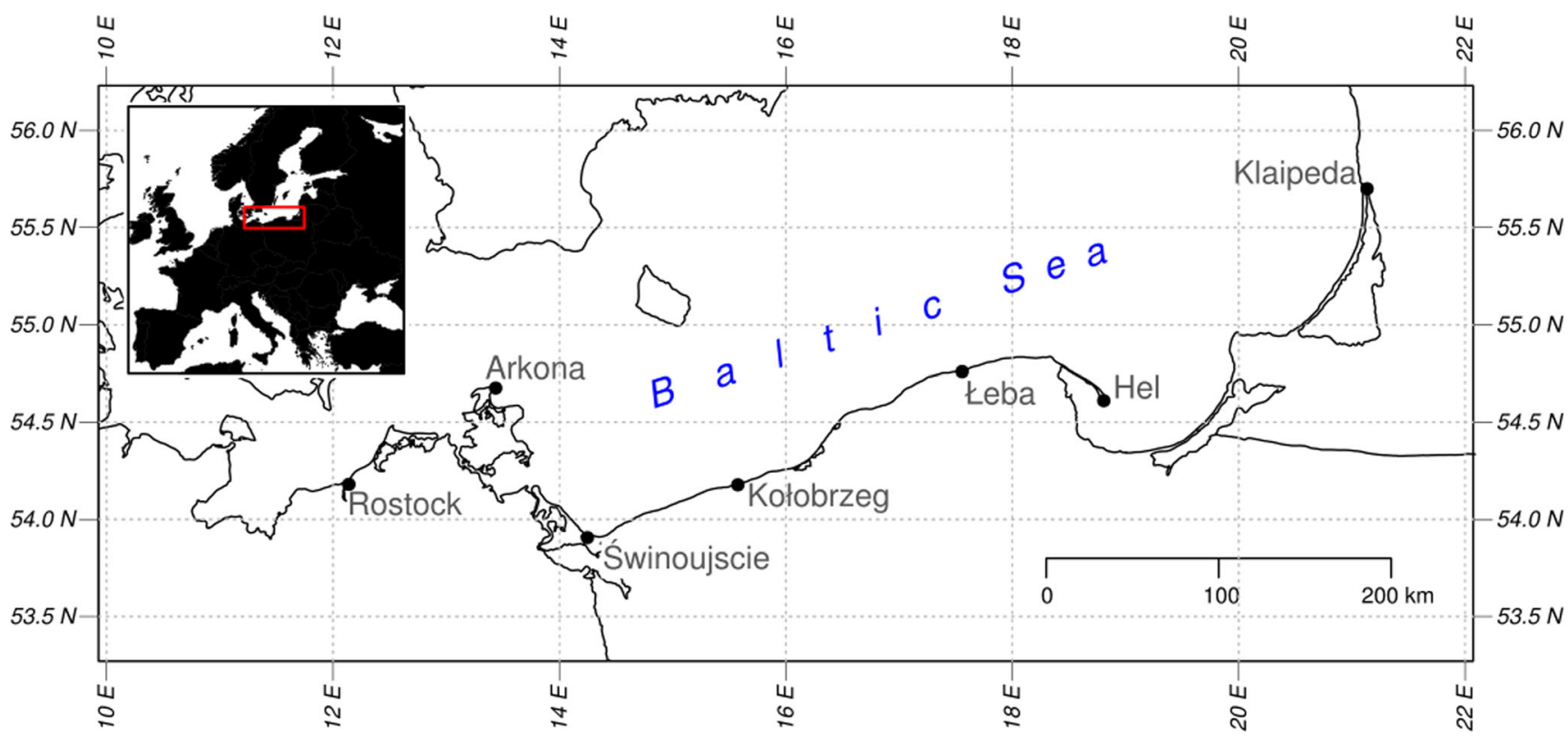

Fig. 1 The research area and the location of chosen stations 
stations (Klaipeda and Hel), and group 3 comprises four stations (Łeba, Kołobrzeg, Świnoujście, and Rostock).

In order to determine typical synoptic situations responsible for the occurrence of extreme human-biometeorological conditions, data of the mean SLP and the $500 \mathrm{hPa}$ geopotential height from the National Center for Environmental Prediction (NCEP) and National Center for Atmospheric Research (NCAR) reanalysis for the aforementioned groups were used (Kalnay et al. 1996) for each group of stations. As far as extreme human-biometeorological situations are concerned, the authors considered those in which the UTCI value at 12UTC exceeded $32{ }^{\circ} \mathrm{C}$ (strong, very strong or extreme heat stress) and those lower than $-27^{\circ} \mathrm{C}$ (very strong and extreme cold stress). To concatenate occurrence of UTCI extremes to synoptic conditions, the "environment-to-circulation" approach was used (Yarnal 1993; Dayan et al. 2012; Bednorz et al. 2013). According to this method, atmospheric circulation is classified with respect to a specific set of environmental criteria for a particular phenomenon, in this case the UTCI extremes. Therefore, days of extreme humanbiometeorological situations were grouped by the k-means clustering method (Wilks 2006) which takes into account the mean SLP for every grid point $\left(2.5^{\circ} \times 2.5^{\circ}\right)$ at the EuroAtlantic area for the period 1981-2010 and with computational domain between $10^{\circ}-30^{\circ} \mathrm{E}$ and $40^{\circ}-60^{\circ} \mathrm{N}$. For designated groups of days, composite maps of anomalies, mean sea-level pressure and the $500 \mathrm{hPa}$ geopotential height were constructed.

All calculations and statistical procedures were carried out using the R programming language ( $\mathrm{R}$ Core Team 2015) and its packages: "raster" (Hijmans 2016) dedicated to the spatial analysis, "maps" (Minka and Deckmyn 2016) for drawing up geographical maps, "akima" (Akima and Gebhardt 2015) for interpolating data, and "ncdf4" (Pierce 2013) which provides a high-level R interface for Network Common Data (NetCDF).

\section{Results}

\subsection{Basic statistics of UTCI values}

In selected stations on the southern Baltic coast, days with almost the entire range of UTCI values have appeared. At each station, days with no thermal stress are the most common (from $26 \%$ in Arkona to $42 \%$ in Kołobrzeg) (Fig. 2).

On days where the value of the UTCI is regarded as an aggravation for organisms, fairly frequent are those with the cold stress conditions. Most of them are classified as moderate cold stress (23-28\% per year) and less so as slight cold stress (18-21\% per year). In turn, days with strong and very strong cold stress occur far less likely with varying frequency in the investigated localities. It is significant that the overwhelming incidence of days with strong cold stress appears in Arkona $(21 \%)$ and then in Klaipeda and Leba (respectively 15 and $14 \%$ ). A slightly lower frequency is observed in Rostock and Hel (respectively 11 and 9\%), while in Świnoujście and Kołobrzeg, they occur at a frequency of only 4-6\%. Days with very strong cold stress appear most frequently in Arkona, i.e., at almost $6 \%$ of days. In Klaipeda, Łeba, and Rostock, these days appear far less frequently (1-1.8\%). In other stations, they occur with a frequency of $0.1-0.7 \%$. Conditions of extreme cold stress appear sporadically in the study area.

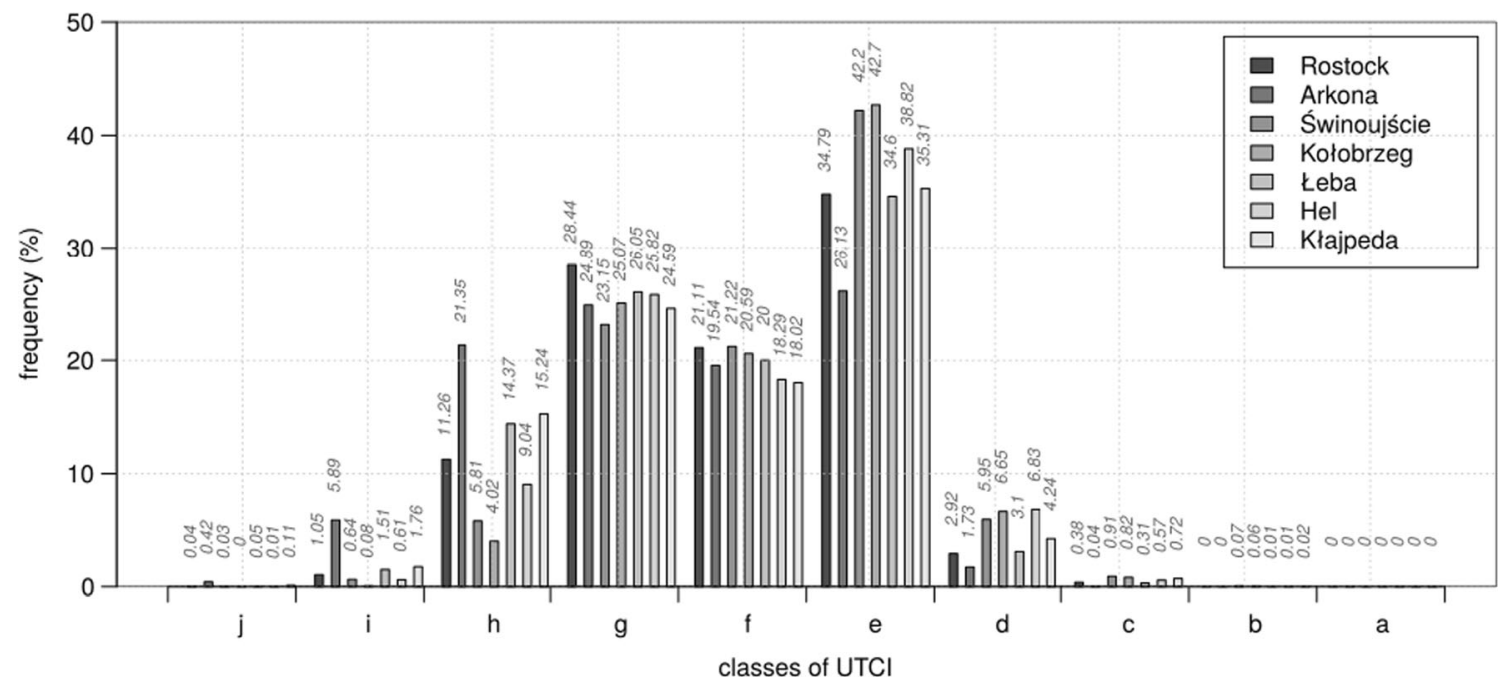

Fig. 2 Frequency (\%) of the number of days according to UTCI categories (12 UTC) in studied stations of the southern Baltic coast (1981-2014). Explanations: a — extreme heat stress, b — very strong heat

stress; c-strong heat stress, d-moderate heat stress, e-no thermal stress, f-slight cold stress, g-moderate cold stress, h-strong cold stress, $\mathrm{i}$ - -very strong cold stress, $\mathrm{j}$ - extreme cold stress 

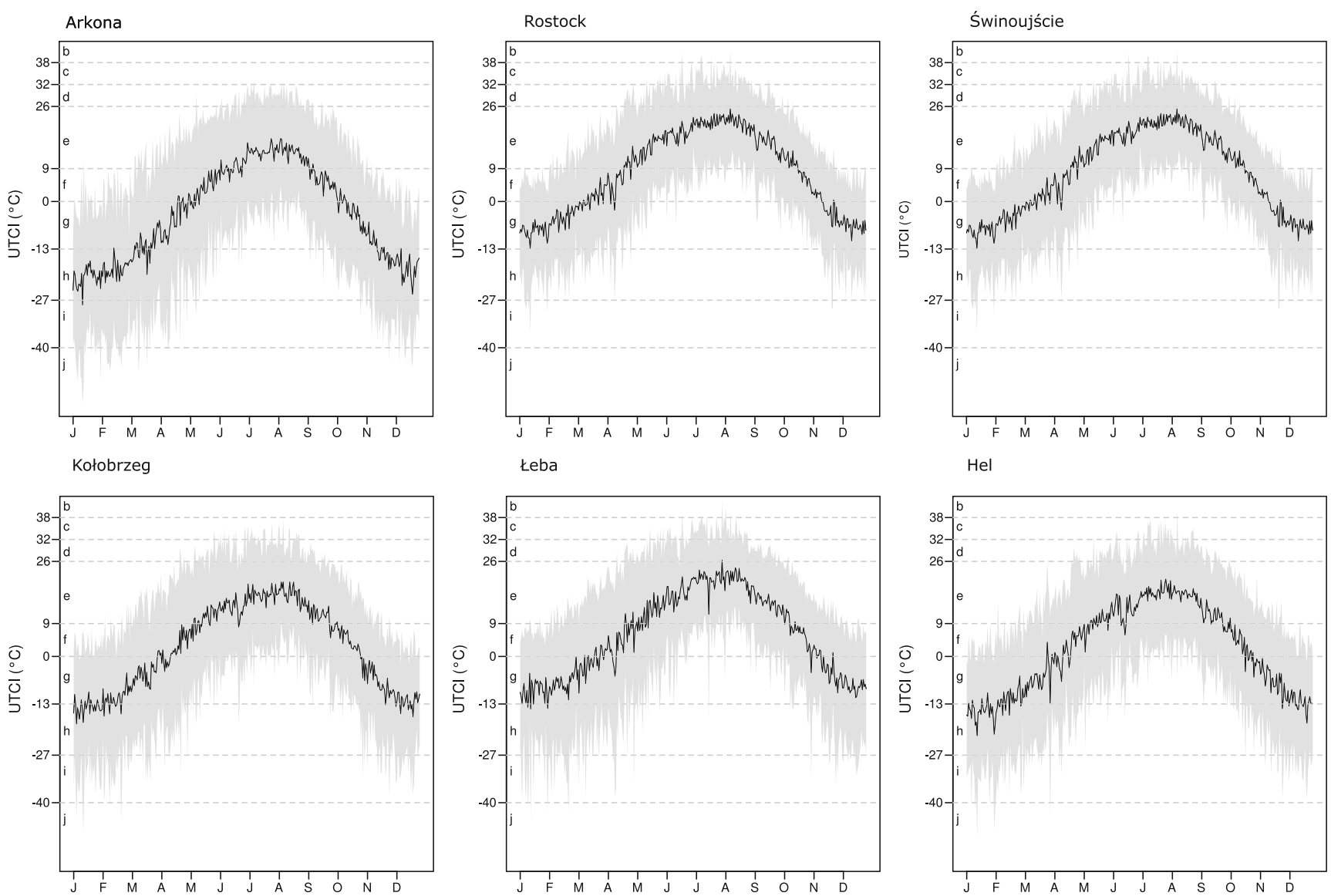

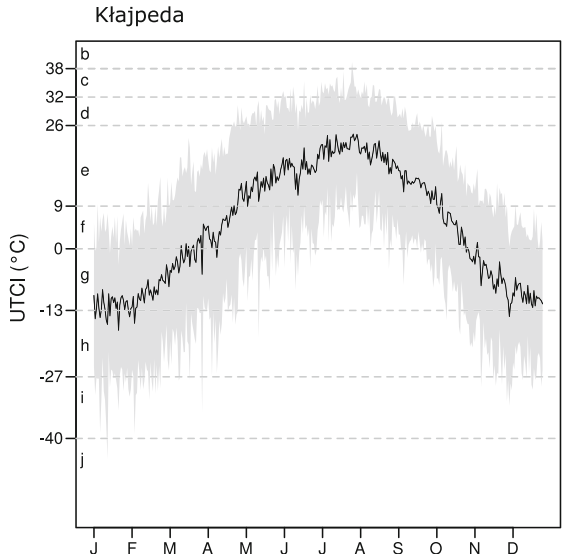

Fig. 3 Annual course of average (line), maximum, and minimum (shaded area) values of the UTCI in studied stations of the southern Baltic coast (1981-2014). Explanations: b - very strong heat stress, c-

Among days with conditions of heat stress, moderate heat stress is the most frequent. In this category of the UTCI, the lowest frequency compared to the other stations is found in Arkona (1.7\%). In Rostock, Łeba, and Klaipeda, these days represent about 3-4\%, and these appear most often in Świnoujście, Kołobrzeg, and Hel (6-7\%). Days from the category of "strong heat stress" appear in Świnoujście, Kołobrzeg, Klaipeda, and Hel at a frequency of approx. $0.6-0.9 \%$ and significantly less frequent in Łeba and Rostock (approx. 0.3\% of all cases). They strong heat stress, $\mathrm{d}$-moderate heat stress, e- no thermal stress, $\mathrm{f}-$ slight cold stress, g-moderate cold stress, $\mathrm{h}$ - strong cold stress, $\mathrm{i}$ very strong cold stress, $j$ - extreme cold stress

occur in Arkona occasionally (less than $0.1 \%$ ). Days with a very strong heat stress in the studied cities occur only in single cases, while days of extreme heat stress do not appear at all.

\subsection{Temporal variability of UTCI on the southern Baltic coast}

The course of the annual average, maximum, and minimum daily values of the UTCI, smoothed out by a 7-day moving 


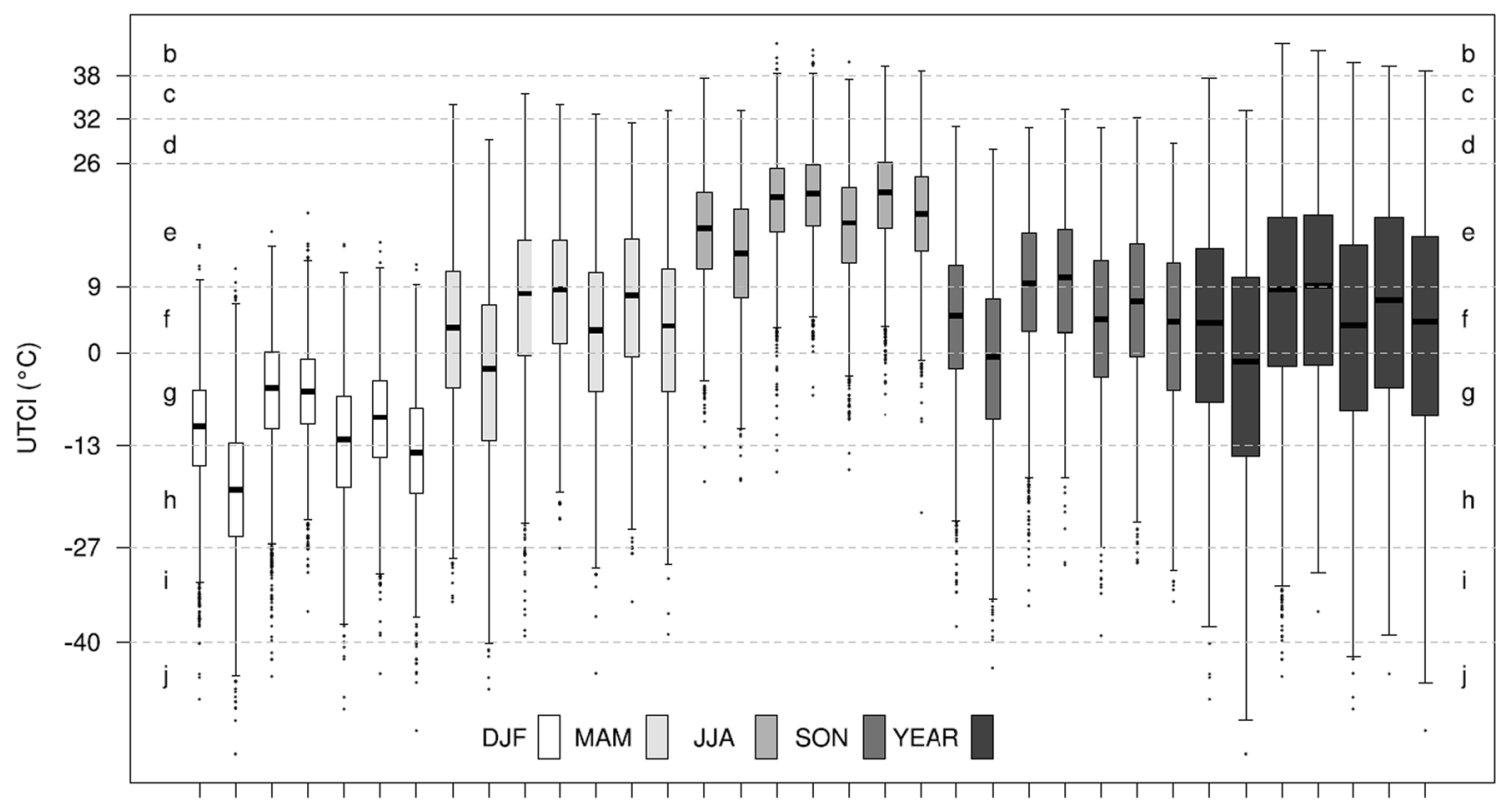

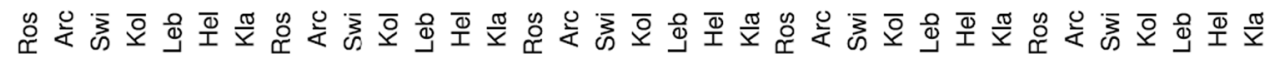

Fig. 4 Box and whisker plots of UTCI statistics in the period of 19812014 in particular stations (Arc-Arkona, Kla-Klajpeda, KolKołobrzeg, Leb-Leba, Ros-Rostock, Swi-Świnoujście) and seasons of the year. Middle values denote medians, the box extends to the Q1 (first quartile) and Q3 (third quartile), and the whiskers show the range (99.3\%): the upper whisker shows Q3 $+1.5 \times \mathrm{IQR}$ (the interquartile range), and the lower shows Q1 $-1.5 \times$ IQR. The points represent outliers. The box widths are proportional to the square roots of the number of observations in the groups. For further explanations, see Fig. 2 average, indicates the presence of a number of significant differences in human-bioclimatic conditions within the area of the southern Baltic coast (Fig. 3). The most evident differences refer to the course of UTCI and the occurrence of the greatest amplitude throughout the year in Arkona. The period with no thermal stress is the shortest there, as it lasts only from the middle of June to the end of August. The maximum UTCI values do not achieve the level of extreme heat stress, while Arkona is characterized by the longest period of strong cold stress, lasting from mid-November until the last week of March. At this time, the minimum UTCI values repeatedly reach the level of a very strong cold stress. In Kołobrzeg and Hel, the period with the highest average UTCI values in terms of a lack of thermal stress lasts on average from the middle of May to early October, while at the other stations, it is much longer and lasts on average from the end of April to the middle of October (Fig. 3). The maximum values of the UTCI at this time predominantly reach the level of moderate heat stress, while the other stations often indicate the range of strong heat stress. On the other hand, in winter, especially in January and February, the average values of the UTCI in Kołobrzeg, Hel, and Klaipeda often run below the threshold of strong cold stress, while the other stations remain in the category of moderate cold stress.

The annual values of the UTCI on the southern Baltic coast indicate that in all studied stations except Arkona, half of the days throughout the year belong to three categories, i.e., no thermal stress, slight cold stress, and moderate cold stress
(Fig. 4). In Arkona, the days of strong cold stress are also included. Unlike the other stations, Arkona is distinguished by the lack of days with very strong heat stress and the occurrence of days in the category of extreme cold stress, which does not appear, for example, in Kołobrzeg at all, and in only a few cases in the other stations.

In the period from March to May, the upper range of UTCI values indicates that the presence of, at almost every station, the conditions of one category was lower compared to the year, i.e., at all stations in spring (apart from Arkona), the days of strong heat stress may well be the most frequent to occur (Fig. 4). In Arkona, spring days in this category are absent (maximum heat stress is achieved with moderate intensity); however, only (ignoring outliers) days of extreme cold stress are present there. In other stations, among cold stress days in spring, days with a strong or very strong cold stress may occur. Approximately half of all spring days in Rostock, Świnoujście, Łeba, Hel, and Klaipeda reach the category of no thermal stress, slight, or moderate cold stress, whereas in Kołobrzeg, there are categories of no heat stress and slight cold stress and in Arkona slight or moderate cold stress.

During the year, the range of UTCI values is narrowest in summer. The upper limit of this range reaches the category of very strong heat stress in four stations (Klaipeda, Hel, Świnoujście, and Kołobrzeg) and the lower category of strong heat stress in the other three (Rostock, Arkona, Łeba). On the other hand, in Świnoujście, Kołobrzeg, and Hel, the lower 


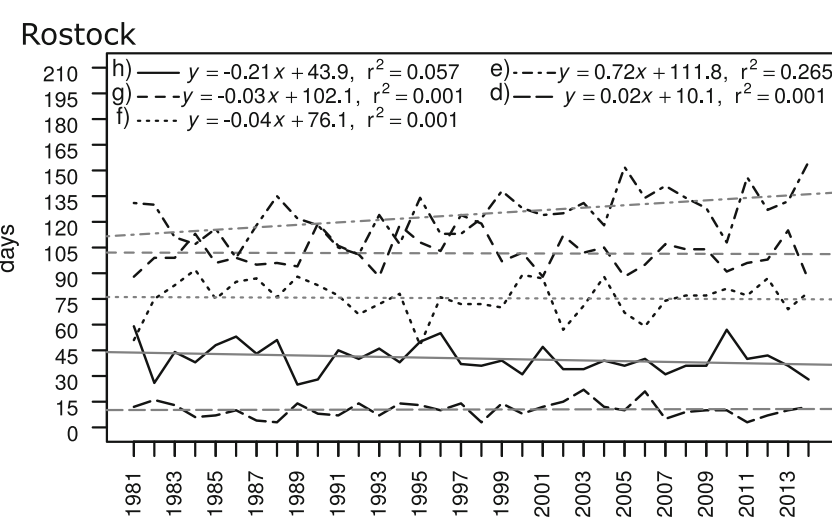

Świnoujście

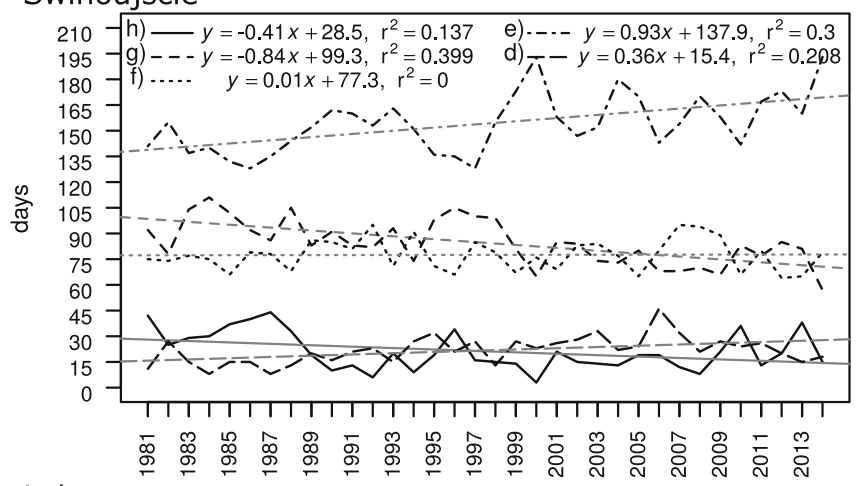

Łeba

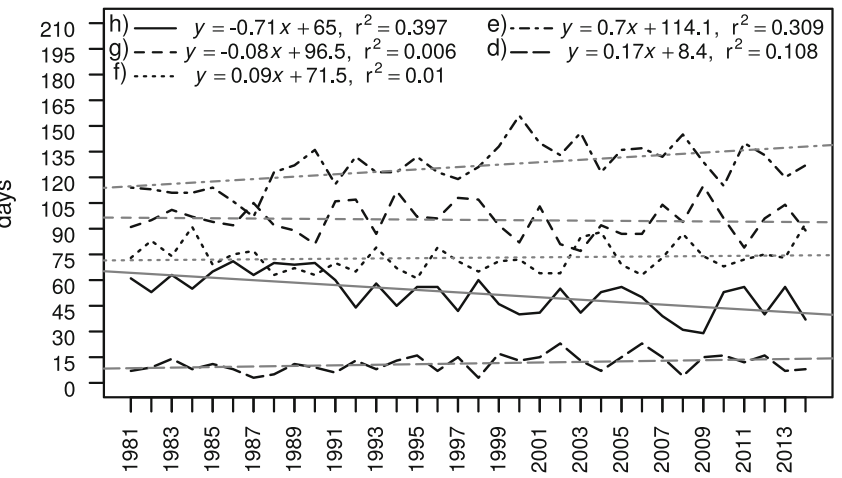

\section{Kłajpeda}

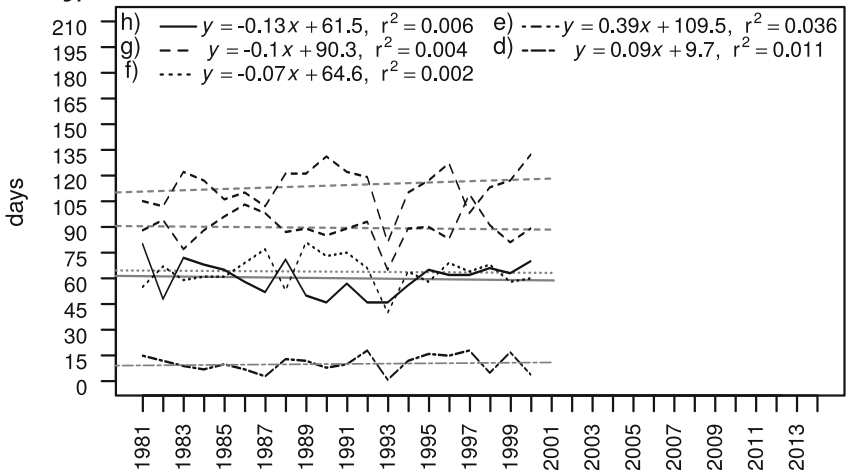

Fig. 5 Multiannual course of the annual number of days for selected categories of UTCI values with linear trends and regression equations in studied stations of the southern Baltic coast (1981-2014).

\section{Arkona}

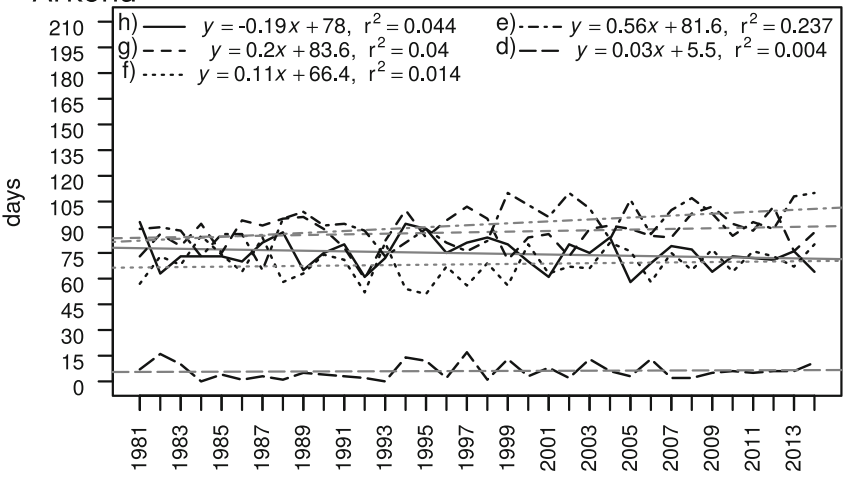

\section{Kołobrzeg}

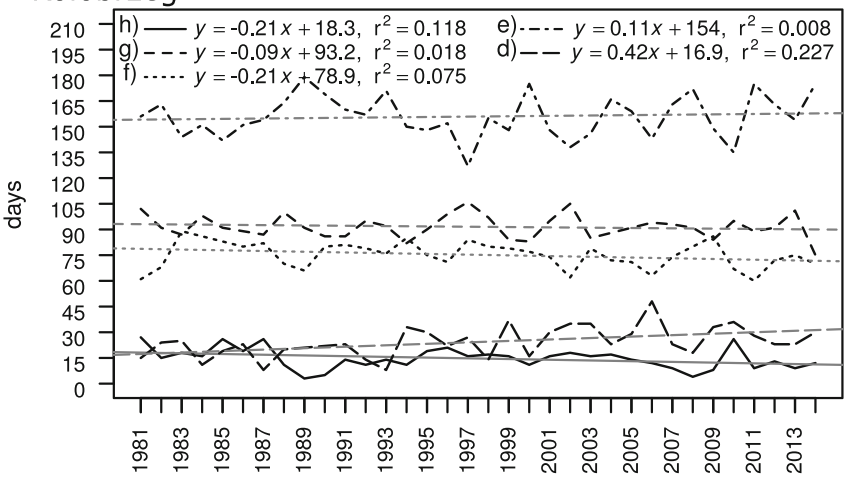

Hel

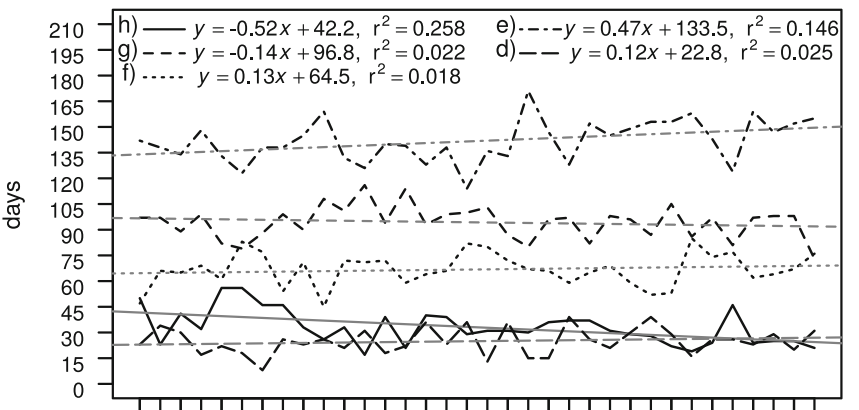

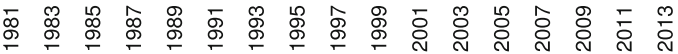

Explanations: $\mathrm{d}$ - moderate heat stress, e - no thermal stress, $\mathrm{f}-$ slight cold stress, $\mathrm{g}$ - moderate cold stress, $\mathrm{h}$ - strong cold stress 


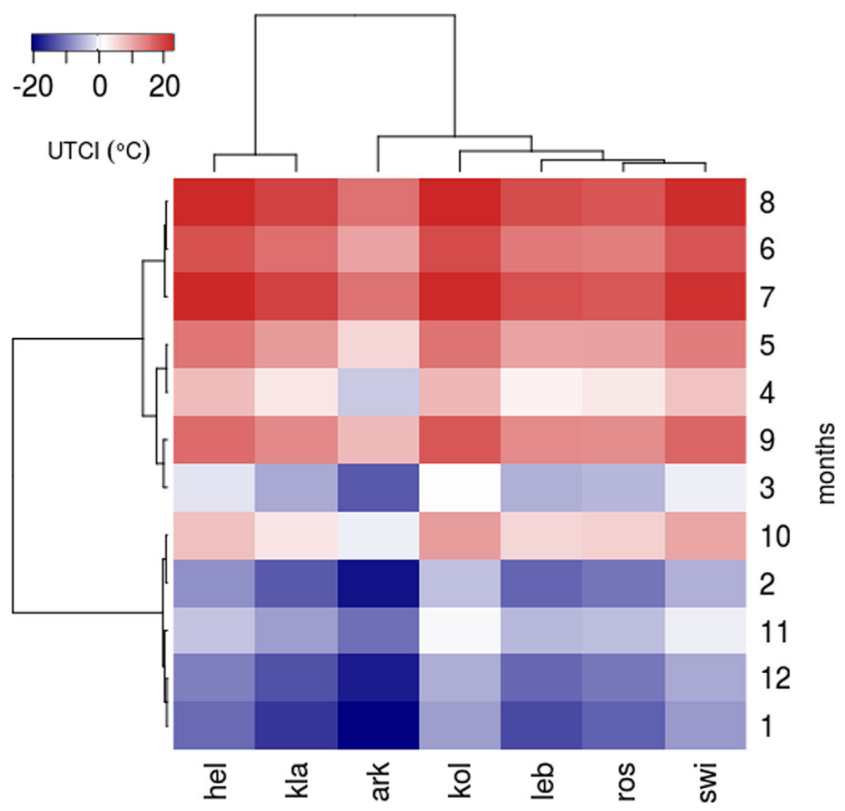

Fig. 6 Heat map of mean monthly UTCI values $\left({ }^{\circ} \mathrm{C}\right)$. Data from the period 1981-2014 (stations: hel—Hel, kla—Klaipeda, ark—Arkona, kol—Kołobrzeg, leb—Leba, ros—Rostock, swi—Świnoujście)

range in UTCI values shows the possibility of days with a slight cold stress and occasional days with moderate cold stress or even with a strong cold stress in summer (two cases in Świnoujście). In the other stations (Rostock, Arkona, Łeba, and Klaipeda), cold days in summer reach the categories of moderate cold stress and individual cases of strong cold stress. For most of the study area, approximately half of all summer days are days with no thermal stress. Only in Arkona do those days belong to two categories, i.e., no thermal stress or slight cold stress.

In autumn, the UTCI values indicate the possibility of a wide range of thermal stress appearances. Compared to those in spring, the autumn maximum values in Rostock, Świnoujście, Łeba, and Klaipeda reach a lower category, i.e., moderate heat stress. This category (as in spring) also occurs in Arkona and Hel, while in Kołobrzeg (in both spring and autumn), there may be days with strong heat stress. Among the cool autumn days, the categories strong and very strong cold stress are the lowest. In this case, Arkona is a distinguished station, where conditions often belong to the very strong cold stress category, and there are even days with extremely strong cold stress. In the study area, half of autumn days are days with no thermal stress, slight, or moderate cold stress. During warmer autumn days, the stations in Świnoujście and Kołobrzeg are different, where half of such days belong to no thermal stress or slight cold stress categories. On the other hand, the station of Arkona stands out because of the more frequent occurrence of days with moderate cold stress compared to other locations.
In winter, the range of highest UTCI values reaches the no thermal stress category in all stations except Arkona. For this station, the calculated index values are in the lower category of slight cold stress. In fact, the lowest index range there reaches the category of extreme cold stress, which occurs in the other stations only occasionally (outliers, representing a maximum of $0.07 \%$ of all cases). Analysis of $50 \%$ of the calculated UTCI values (a gap between the first and third quartile) also indicates the presence of more severe conditions of thermal stress in Arkona (strong cold stress), while in Świnoujście and Kołobrzeg, it falls into the category of moderate cold stress. The other stations cover a range of moderate to strong cold stress for the same half days.

On the basis of annual frequency of the most common category of the UTCI, linear trends were calculated for all investigated stations (Fig. 5). Days of moderate heat stress, which appear on average to range from approx. 6 (Arkona) to approx. $24(\mathrm{Hel})$, exhibit a positive trend for all tested stations. This trend is statistically significant in the central part of the Baltic coast (Świnoujście and Kołobrzeg $\alpha=0.01$; Łeba $\alpha=0.1$, where the pace of change varies from approx. 2 to 4 days in 10 years. Days with no thermal stress, which appear on average to range from 94 days per year in Arkona to 153 in Świnoujście, also show an upward trend in the rate of about 59 days in 10 years - statistically significant at all stations except for Kołobrzeg. At the same time, as to the frequency of days with severe cold stress, occurring in the study area on average from 14 (Kołobrzeg) to 77 times a year (Arkona), there is a decreasing trend. In this case, statistically significant trends are seen in Kołobrzeg ( 2 days $/ 10$ years, $\alpha=0.1$ ), Łeba ( 7 days/10 years, $\alpha=0.001$ ), and Hel ( 5 days/10 years, $\alpha=0.01$ ). In all studied stations except Arkona, there is also a decrease in the number of days with moderate cold stress, which is statistically significant only in Świnoujście (8 days/ decade, $\alpha=0.001$ ) where 84 days in this category occur. The number of days with slight cold stress has a positive trend in Arkona, Świnoujście, Łeba, and Hel and a negative one in Rostock, Kołobrzeg, and Klaipeda even though such a trend is not statistically significant.

\subsection{UTCI values depending on weather types}

The results of station and monthly UTCI value grouping are shown in Fig. 6. As already mentioned in the methods chapter, stations taken into consideration were classified into three groups ( $x$-axis). Group 1 comprised only one station (Arkona). Group 2 comprised two stations (Klaipeda and Hel), and group 3 comprised four stations (Łeba, Kołobrzeg, Świnoujście, and Rostock). In addition, the analysis of Fig. 6 ( $y$-axis) indicates a division of the year into summer months with the highest averaged UTCI values (period from June to August), a cold part of the year (period from October to 
Fig. 7 Average synoptic situation favorable for UTCI values above $32{ }^{\circ} \mathrm{C}$ in Arkona. TI, TII, and TIII denote three different types of SLP pattern (left column-a) and their anomalies (right columnb). Solid lines denote SLP pattern $(\mathrm{hPa})$, and dotted lines denote $500 \mathrm{hPa}$ geopotential height $(\mathrm{m}$ a.s.1.)
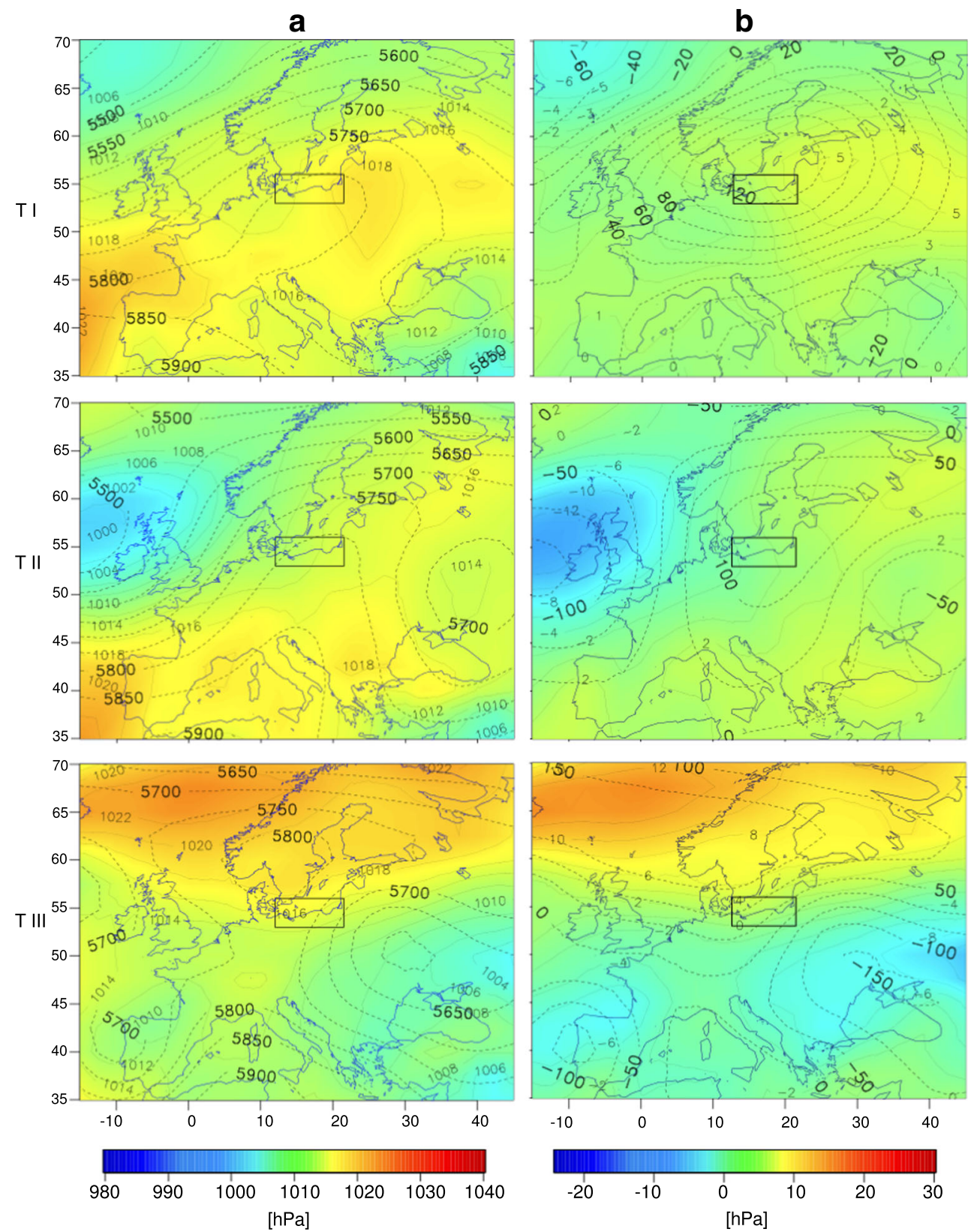

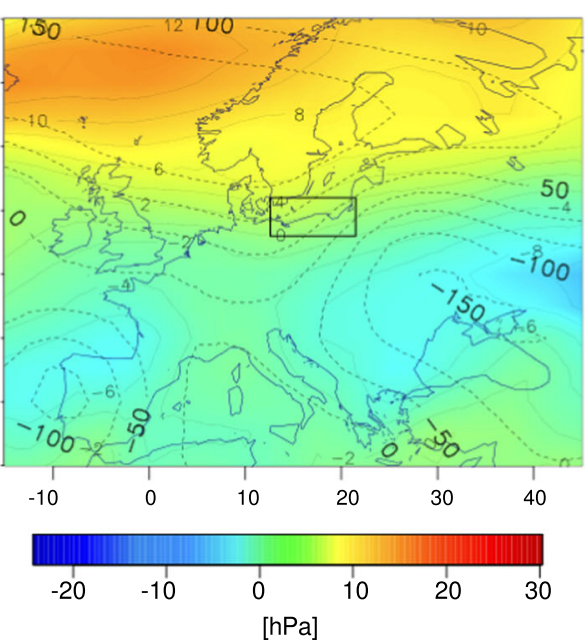

February), and transitional months (period from March to May and September).

In the next part of the study, to identify the macro-scale circulation conditions favorable for days with extreme UTCI values (UTCI $>32{ }^{\circ} \mathrm{C}$ and UTCI $<-27^{\circ} \mathrm{C}$ ), maps of SLP pattern and $500 \mathrm{hPa}$ geopotential height for each distinguished group of stations were grouped, and results of grouping were analyzed as an average synoptic situation.

\subsection{Synoptic situations in days with UTCI values above $32{ }^{\circ} \mathrm{C}$}

For the Arkona station, three types of synoptic situations responsible for UTCI $>32{ }^{\circ} \mathrm{C}$ were identified. In the first type, the southern Baltic area is under the influence of a warm air mass flowing from the southwest. The influx is due to the influence of the high-pressure center located east of the Polish border and a wedge of high pressure associated with the Azores High. The izohips system determining the level of the $500 \mathrm{hPa}$ geopotential height denotes the presence of warm air masses over a large area of western and central Europe. Over the area of the southern Baltic, the surface of $500 \mathrm{hPa}$ is more than $120 \mathrm{~m}$ higher than the average conditions, which clearly indicates an increase in the air masses' temperature (Fig. 7).

In the second type of synoptic situations concerning days with high UTCI values, the warm air reaches the area of research from the south, which is due to systems of high pressure that developed over the area of the Mediterranean and Balkan Peninsula. 

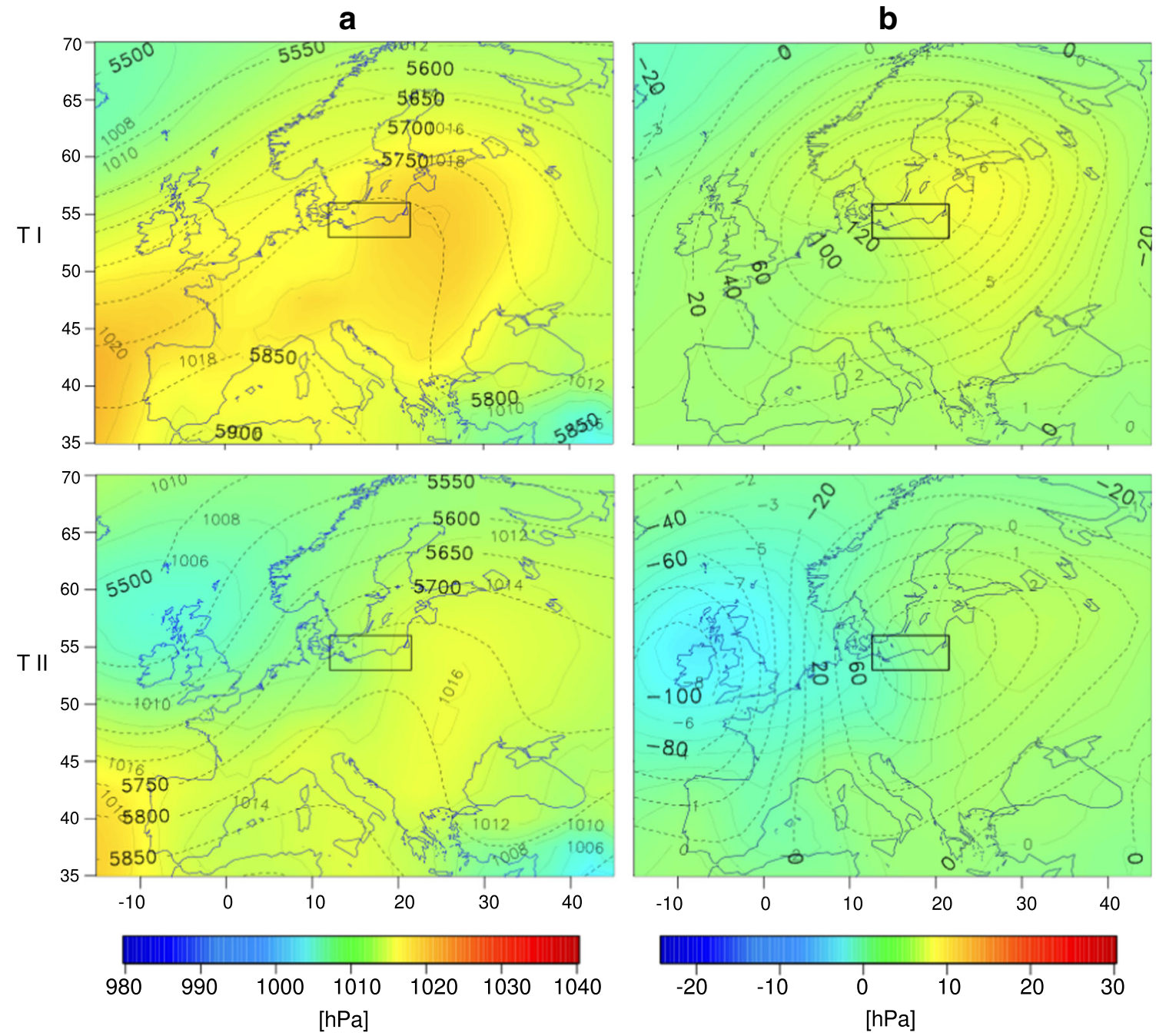

Fig. 8 Average synoptic situation favorable for UTCI values above $32{ }^{\circ} \mathrm{C}$ for the second group of stations. TI and TII denote two different types of SLP pattern (left column-a) and their anomalies (right

The surface $500 \mathrm{hPa}$ height is clearly higher over the southern and central parts of Europe, while the southern and central Baltic area is covered by air masses that are warmer than usual. The altitude of occurrence of an isobaric surface $500 \mathrm{hPa}$ in this region is $100 \mathrm{~m}$ higher than the average conditions (Fig. 7).

In the third type of synoptic situations, the study area is located on the edge of the high-pressure area centering over the Norwegian Sea. This pressure system causes a flow of air over the southern Baltic coast from the east, only to be amplified by the impact of the low-pressure area, the center of which is over the northeast of the Black Sea. The isobaric surface over the research area is about $50 \mathrm{~m}$ higher than the average conditions, indicating an increase in temperature in this region (Fig. 7).

For group 2 (Klajpeda and Hel), two types of synoptic situation responsible for UTCI $>32{ }^{\circ} \mathrm{C}$ were identified. The high values of UTCI are due to the influx of warm air masses from the south in both first and second types of synoptic situation. In the first group, the study area is influenced by a high, the center column - b). Solid lines denote SLP pattern (hPa), and dotted lines denote $500 \mathrm{hPa}$ geopotential height (m a.s.l.)

of which lies northeast of Poland. Warm air masses cover almost all of Europe and the western part of the Mediterranean Basin, as indicated by the characteristic bend of geopotential $500 \mathrm{hPa}$ izohips to the north. Over the region of the southern Baltic, the isobaric surface of $500 \mathrm{hPa}$ height is $120 \mathrm{~m}$ higher than average conditions. In the second group of days, the high-pressure area is weaker than that described for the first group, and the isobaric surface of $500 \mathrm{hPa}$ height is on the southern Baltic over $60 \mathrm{~m}$ higher than average conditions (Fig. 8).

For group 3 (Kołobrzeg, Łeba, Świnoujście, and Rostock), two types of synoptic situation responsible for UTCI $>32{ }^{\circ} \mathrm{C}$ were distinguished. In both types, the research area is located on the edge of a high, the center of which lies to the east of the Gulf of Finland. This generates an influx of warm air masses from the south over central Europe. In the second type, the high is weaker; however, advection from the south is strengthened by the influence of a low-pressure area over the British Isles. In both cases, the $500 \mathrm{hPa}$ geopotential surface position 

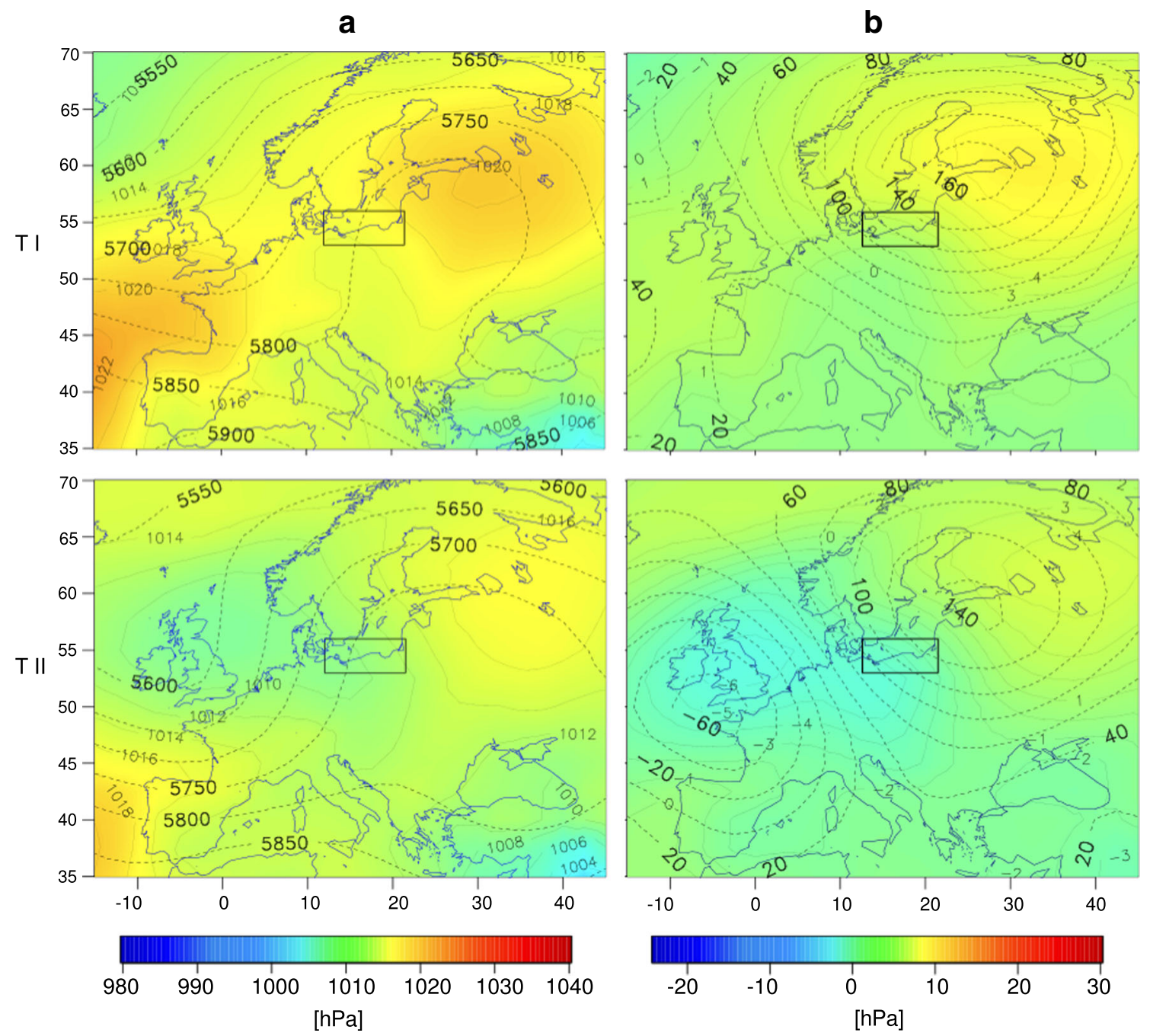

Fig. 9 Average synoptic situation favorable for UTCI values above $32{ }^{\circ} \mathrm{C}$ for the third group of stations. TI and TII denote two different types of SLP pattern (left column-a) and their anomalies (right

is higher by more than $100 \mathrm{~m}$ than the average conditions over the study area (Fig. 9).

\subsection{Synoptic situations in days with UTCI values below $-27^{\circ} \mathrm{C}$}

For group 1 (Arkona), three groups of synoptic situation types responsible for UTCI $<-27{ }^{\circ} \mathrm{C}$ were distinguished. In all types of synoptic situations (shown in Fig. 10), a much larger pressure gradient over the area of research than in types with high UTCI values is observed. This means that the cause of extremely low index values in these types, in addition to the low air temperature, is also high wind speed.

The first type (TI) is characterized by the advection of air masses over the research area from the southeast, generated by a very deep high-pressure system centering over Scandinavia and significant areas of the Baltic Sea. During these days, the $500 \mathrm{hPa}$ geopotential height in the area of the southern part of column-b). Solid lines denote SLP pattern (hPa), and dotted lines denote $500 \mathrm{hPa}$ geopotential height (m a.s.l.)

the Baltic Sea is about $20 \mathrm{~m}$ lower than in average conditions, but the characteristic geopotential height line deflection to the southwest over central Europe demonstrates a clear cold advection from the eastern part of the high.

In the second type (TII), a western air flow over the area of research is observed, the result of a deep low-pressure impact whose center is over the Norwegian Sea and central Baltic Sea. The $500 \mathrm{hPa}$ geopotential height is about $200 \mathrm{~m}$ lower over the southern Baltic coast than in average conditions.

In the third type of synoptic situation (TIII), the extremely low UTCI values also occur in a situation with western inflow of air masses; however, the low in this case is weaker and located further north, while the southern Baltic coast is under the direct influence of a high whose center is over significant areas of France and Spain. The geopotential height in these days is similar to the average (Fig. 10).

For group 2 (Klajpeda and Hel), three groups of synoptic situation types responsible for UTCI $<-27{ }^{\circ} \mathrm{C}$ were 

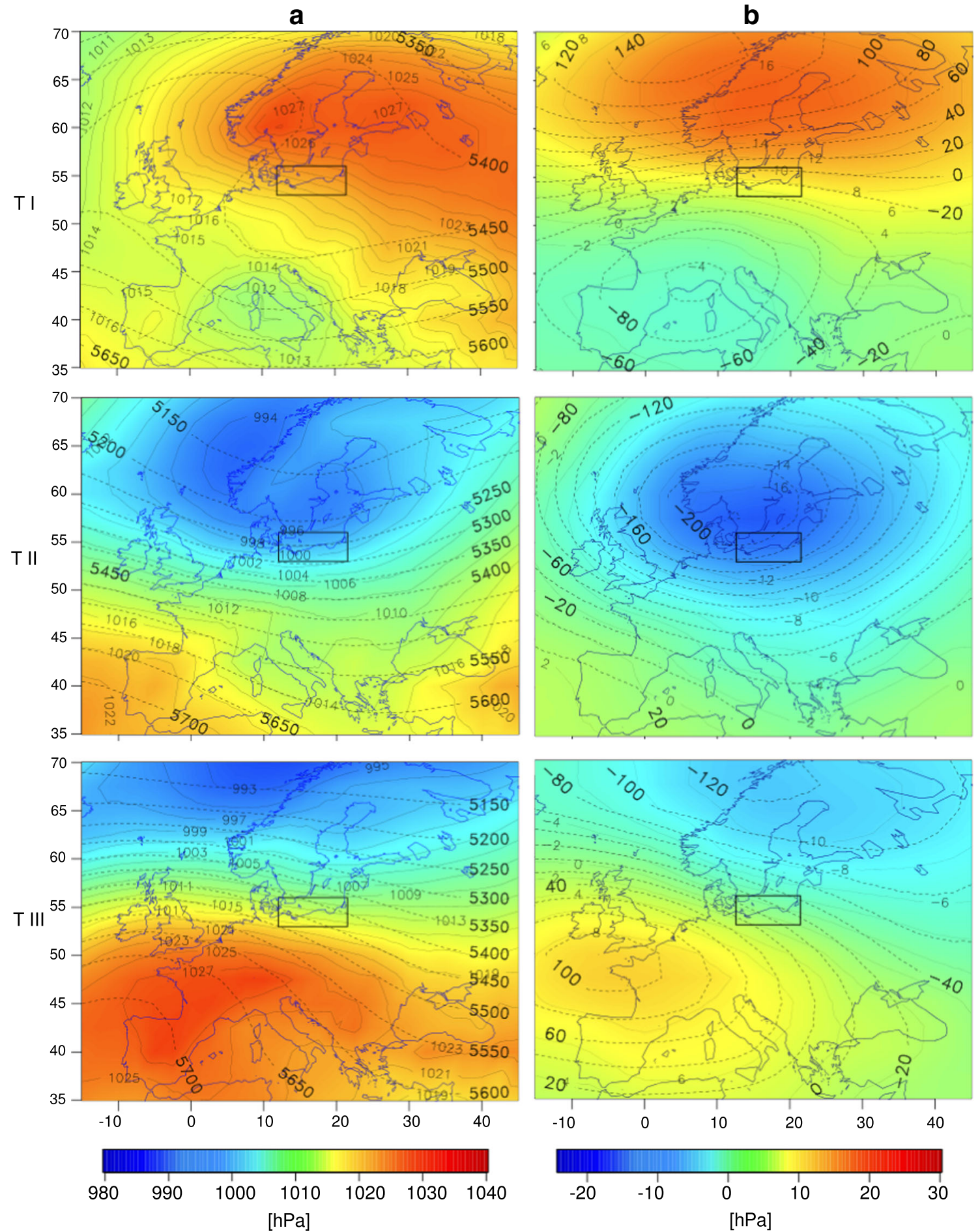

Fig. 10 Average synoptic situation favorable for UTCI values below $-27^{\circ} \mathrm{C}$ in Arkona. TI, TII, and TIII denote three different types of SLP pattern (left column - a) and their anomalies (right column - b). Solid lines denote SLP pattern (hPa), and dotted lines denote $500 \mathrm{hPa}$ geopotential height (m a.s.1.)

distinguished. Extremely low UTCI values occur during both zonal and meridional air flow over the southern Baltic coast. In the first type of synoptic situation, the advection from the east is due to the impact of a very deep high-pressure system, the center of which covers the whole of Scandinavia and the Baltic. Laying izohips of the $500 \mathrm{hPa}$ geopotential surface indicates a clear cold advection over most of Europe. In these days, the height of the $500 \mathrm{hPa}$ isobaric surface is only a few meters lower than in the average conditions.

In the second type, the advection of cold air from the north over the research area is observed. Such an advection is caused by the impact of a low-pressure system over 
the Baltic. The location of $500 \mathrm{hPa}$ geopotential over the southern part of the Baltic Sea is in this case more than $200 \mathrm{~m}$ lower than average.

Similar to the first type, the third type is characterized by the advection of cold air from the northeast over large areas of Europe, including the southern Baltic coast. This situation is also due to the influence of a high-pressure system located over Scandinavia, but in this case, the high is much shallower, while the advection enhances the impact of the low pressure whose center is over the northern part of the Mediterranean Sea and Apennine Peninsula. The geopotential height of the study area is lower than the average by more than $100 \mathrm{~m}$ (Fig. 11).

For group 3 (Kołobrzeg, Łeba, Świnoujście, and Rostock), three types of synoptic situation responsible for UTCI $<-27^{\circ} \mathrm{C}$ were distinguished. Extremely low UTCI values in the first type are associated with the impact of a deep high-pressure system located east of the central part of the Baltic Sea that generates a south eastern advection of air over the southern Baltic coast. In this case, the geopotential height over the research area is close to average.

The second type of synoptic situations is characterized by a strong zonal flow of air over the study area from the west, caused by the impact of a deep lowpressure system over the southern part of the Norwegian Sea. The geopotential height over the southern Baltic coast in the days of analysis is about $160 \mathrm{~m}$ lower than average.

In the third type of synoptic situations, the advection of cold air from the northwest over the research area is observed, to be associated with the impact of a low-pressure system located east of the northern Baltic Sea and the vast highpressure system whose center is over significant areas of Western Europe. The geopotential height over the designated part of the southern Baltic coast is lower than the average by more than $100 \mathrm{~m}$ (Fig. 12).

\section{Discussion and conclusion}

This study is aimed at a temporal and spatial analysis of bioclimatic conditions in the southern Baltic coast on the basis of the UTCI. Moreover, by means of observational data from the coastline stations as well as reanalysis data, the authors attempt to explain which synoptic situations are conducive to the occurrence of days with very strong and extreme cold or heat stress.

The annual ranges of UTCI value with regard to the southern Baltic coast indicate that in all studied stations except Arkona, half of all days within the year belong to three categories, i.e., no thermal stress, slight cold stress, and moderate cold stress. In Arkona, the range also includes days of strong cold stress. In contrast to the other stations, Arkona differs by the lack of days with very strong heat stress, and the occurrence of days with extreme cold stress which does not appear at all in Kołobrzeg, and at the other stations in only a few cases.

The most common are days with no thermal stress (26$42 \%$ of all investigated days). In the category of cold stress, the days with moderate cold stress (23-28\%) and slight cold stress (18-21\%) dominate. At all investigated stations excluding Arkona, a decrease in the number of days with moderate cold stress is observed, which is statistically significant only in Świnoujście (8 days/decade, $\alpha=0.001$ )

Days with strong cold stress are less frequent (4-21\%), while days with very strong cold stress appear with a frequency ranging from 0.1 to $0.7 \%$ (Świnoujście, Kołobrzeg, and Hel) to almost $6 \%$ (Arkona). The terms of extreme cold stress appear in the study area occasionally (from 0.01 to $0.5 \%$ ).

In days with heat stress, moderate heat stress conditions are most commonly reported. Their frequency varies from $1.7 \%$ in Arkona to 6-7\% in Świnoujście, Kołobrzeg, and Hel. The long-term course of such days on the southern Baltic coast is characterized by a positive trend in all studied stations. However, statistical significance concerns only the central part of the coast. Days with strong heat stress appear in investigated area occur occasionally $(0.3-0.9 \%)$, and days with very strong heat stress occur only in single cases, while days with extreme heat stress do not appear at all.

Days per year with no thermal stress (from 94 in Arkona to 153 in Świnoujście) also show an upward trend in the rate of about 5-9 days in 10 years-statistically significant in almost all stations. In modeling the longterm course of average annual and seasonal UTCI values based on SRES scenarios, Błażejczyk (2013) showed in most analyzed cases a statistically significant upward trend. Moreover, Kazỳs and Malūnavičiūtè (2015), using data from the period 1980 to 2009 , found an increase in the value of UTCI on the whole Baltic coast in the months from May to September.

To date, studies on the impact of atmospheric circulation on UTCI remain rare. Novosad et al. (2013) studied the effects of atmospheric circulation types on UTCI while taking into account the MI (meridional inflow) and ZI (zonal inflow) indicators in Lublin and Lesko. The authors found seasonal variation in the circulation's impact on the UTCI, estimating that the zonal and azonal circulation explains 11 to $26 \%$ of the UTCI variance.

To analyze the influence of atmospheric circulation on extreme UTCI values, stations taken into consideration were classified into three groups. Group 1 comprised only one station (Arkona); group 2 had two stations (Klajpeda 

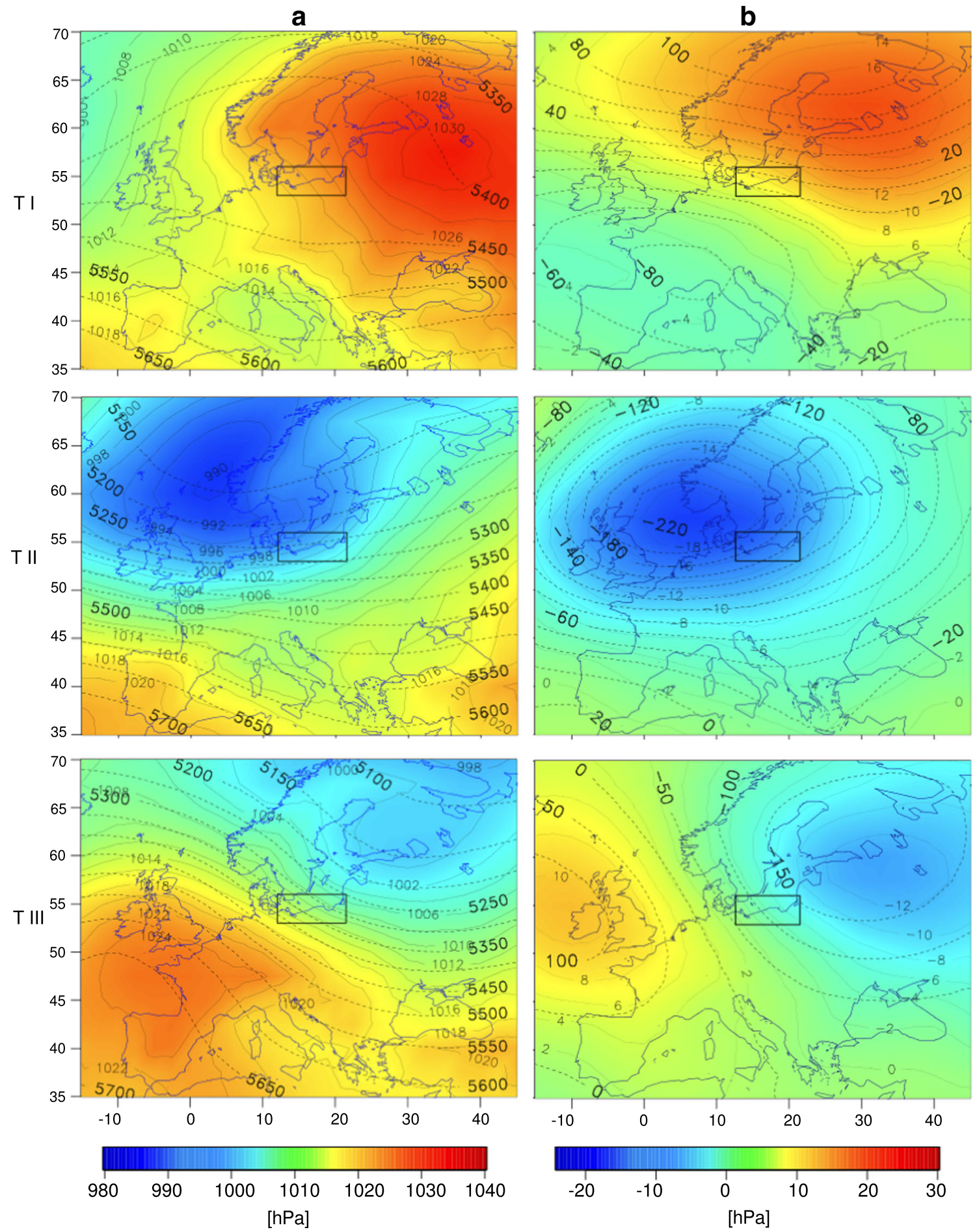

Fig. 11 Average synoptic situation favorable for UTCI values below $-27^{\circ} \mathrm{C}$ for the second group of stations. TI, TII, and TIII denote three different types of SLP pattern (left column - a) and their anomalies (right

column-b). Solid lines denote SLP pattern (hPa), and dotted lines denote $500 \mathrm{hPa}$ geopotential height (m a.s.l.)

and Hel), while group 3 consisted of four stations (Łeba, Kołobrzeg, Świnoujście, and Rostock).

Extremely high UTCI values (UTCI $>32{ }^{\circ} \mathrm{C}$ ) tend to appear in the study area during the period from mid-May to mid-September. In Arkona, they occur only in summer during advection of warm air masses from the south caused by the impact of high-pressure systems whose center is over eastern or southern Europe. In a few cases, the advection of warm air from the east was observed to have been influenced by the interaction of a deep high- 

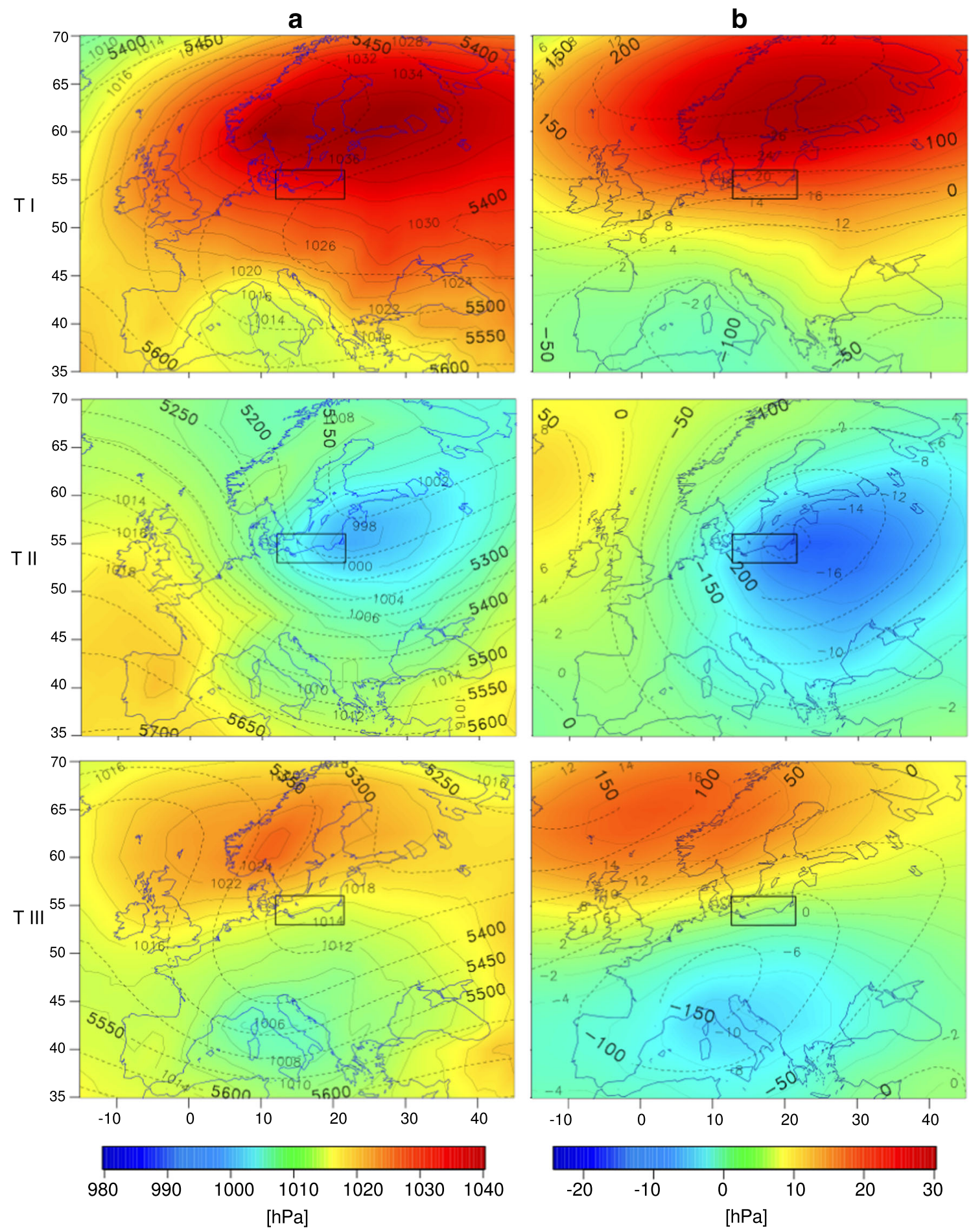

Fig. 12 Average synoptic situation favorable for UTCI values below $-27{ }^{\circ} \mathrm{C}$ for the third group of stations. TI, TII, and TIII denote three different types of SLP pattern (left column-a) and their anomalies

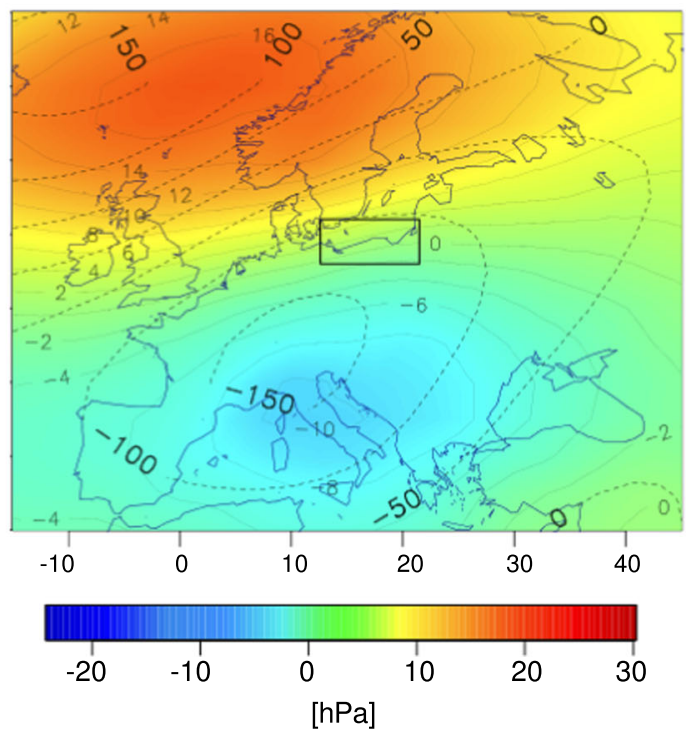

(right column - b). Solid lines denote SLP (hPa) distribution, and dotted lines denote $500 \mathrm{hPa}$ geopotential height (m a.s.l.)

pressure system over the Norwegian Sea and a low from over the Ukraine.

In the other two groups of stations, extreme UTCI values (UTCI $>32^{\circ} \mathrm{C}$ ) were related to the direct influence of a highpressure system located east of Poland and advection of warm air masses from the south or the presence of a high-pressure system over the area of Poland.

Extremely low UTCI values (UTCI $<-27^{\circ} \mathrm{C}$ ) can occur at any time of the year except summer. In all station groups, these extremes could be observed during high-pressure 
retention over the Baltic and Scandinavia. In this situation, especially during night hours, there is a strong emission of heat into the higher layers of the atmosphere, such that significant decreases in air temperature are observed. It should be noted that in these situations, the air temperature was low as indicated by the lower-than-average $500 \mathrm{hPa}$ isobaric surface height.

The reported extreme values also occurred during advection from west or northwest, caused by the direct influence of a low-pressure system over the North Sea, southern Scandinavia, and southern Baltic Sea. In these situations, a lower-than-average position of the $500 \mathrm{hPa}$ isobaric surface over the study area was also observed.

Atmospheric circulation is the factor responsible for the occurrence of extreme values among the meteorological elements (Huth et al. 2008; Kyselý 2008). Błażejczyk et al. (2012) notes that air temperature is one of the most responsible factors for the UTCI values. The results of the research confirm the known effect of atmospheric circulation on incidence of hot days in the Baltic coast, mainly during the southern circulation, intermediate between cyclonic and anticyclonic circulation and southern anticyclonic circulation (Ustrnul and Czekierda 2002). Similarly, concerning the whole area of Poland, Wibig (2007) and Ustrnul et al. (2010) notice that the highest air temperature values are associated with the anticyclonic situation, even without the specified advection. In Poland, extreme low temperature is also due to the impact of high-pressure systems (Ustrnul and Czekierda 2002). Therefore, it can be concluded that the synoptic situations conducive to the occurrence of extreme air temperature are also responsible for the occurrence of heat or cold stress, i.e., very high or low UTCI values.

Funding information Leszek Kolendowicz is partially supported by the National Science Center (NCN Poland), grant no. UMO - 2016/21/B/ ST10/01864. Ewa Bednorz is partially supported by the National Science Center (NCN Poland), grant no. UMO - 2016/21/B/ST10/0144.

Open Access This article is distributed under the terms of the Creative Commons Attribution 4.0 International License (http:// creativecommons.org/licenses/by/4.0/), which permits unrestricted use, distribution, and reproduction in any medium, provided you give appropriate credit to the original author(s) and the source, provide a link to the Creative Commons license, and indicate if changes were made.

\section{References}

Akima H, Gebhardt A (2015) Akima: interpolation of irregularly and regularly spaced data. $\mathrm{R}$ package version $0.5-12$. http://CRAN.Rproject.org/package=akima

Bednorz E, Półrolniczak M, Czernecki B (2013) Synoptic condition governing upwelling along the Polish Baltic coast. Oceanologia $55: 767-785$

Błażejczyk K (2011) BioKlima-universal tool for bioclimatic thermophysiological studies. Warszawa: Instytut Geografii i
Przestrzennego Zagospodarowania, PAN, http://www.igipz.pan.pl/ Bioklima-zgik.html. Accessed 20 May 2015

Błażejczyk K (2013) Distribution of universal thermal climate index (UTCI) in Warsaw. Geogr Pol 86:79-80

Błażejczyk K, Bröde P, Fiala D, Havenith G, Holmer I, Jendritzky G, Kampmann B (2010) UTCI - New index for assessment of heat stress in man. Prz Geogr 82(1):49-72

Błażejczyk K, Epstein Y, Jendritzky G, Staiger H, Tinz B (2012) Comparison of UTCI to selected thermal indices. Int $\mathrm{J}$ Biometeorol 56:515-535

Błażejczyk K, Idzikowska D, Błażejczyk A (2013a) Forecast changes for heat and cold stress in Warsaw in the 21 st century, and their possible influence on mortality risk. Pap Glob Chang 20:47-62

Błażejczyk K, Jendritzky G, Broede P, Fiala D, Havenith G, Epstein Y, Psikuta A, Kampmann B (2013b) An introduction to universal thermal climate index (UTCI). Geogr Pol 86:5-10

Błażejczyk K, Baranowski J, Błazejczyk A (2014a) Heat stress and occupational health and safety - spatial and temporal differentiation. Misc Geograph—Reg Stud Dev 18:61-67

Błażejczyk K, Kuchcik M, Błażejczyk A, Milewski P, Szmyd J (2014b) Assessment of urban thermal stress by UTCI-experimental and modelling studies: an example from Poland. Erde 145:16-33

Bröde P, Fiala D, Błażejczyk K, Holmer I, Jendritzky G, Kampmann B, Tinz B, Havenith G (2012) Deriving the operational procedure for the universal thermal climate index (UTCI). Int J Biometeorol 56: 481-494

Bröde P, Krüger EL, Fiala D (2013) UTCI: validation and practical application to the assessment of urban outdoor thermal comfort. Geogr Pol 86:11-20

Dayan U, Tubia A, Levy I (2012) On the importance of synoptic classification methods with respect to environmental phenomena. Int $\mathrm{J}$ Climatol 32:681-694

Guijarro J, (2016) Climatol: climate tools (series homogenization and derived product). $\mathrm{R}$ package version 3.0. http://CRAN.R-project. org $/$ package $=$ climatol

Huth R, Beck C, Phillipp A, Demuzere M, Ustrnul Z, Cahynova M, Kyseĺy J, Tveito O (2008) Classifications of atmospheric circulation patterns: recent advances and applications. Ann N Y Acad Sci 1146: $105-152$

Ge Q, Kong Q, Xi J, Zheng J (2016) Application of UTCI in China from tourism perspective. Theor Appl Climatol. https://doi.org/10.1007/ s00704-016-1731-z

Hijmans R J (2016) Raster: geographic data analysis and modeling. R package version 2.5-8. http://CRAN.R-project.org/package=raster

Idzikowska D (2011) Relationship between mortality and UTCI in Paris, Rome, Warsaw and Budapest. Pr Studia Geogr 47:311-318

International Union of Physiological Sciences-Thermal Commission (2003) Glossary of terms for thermal physiology. J Therm Biol 28: 75-106

IPCC (2014) Climate change 2014: impacts, adaptation, and vulnerability. Part B: regional aspects. Contribution of Working Group II to the Fifth Assessment Report of the Intergovernmental Panel on Climate Change. Cambridge University Press, Cambridge, United Kingdom and New York, NY, USA, 688

Jendritzky G, De Dear R, Havenith G (2012) Why another thermal index? Int J Biometeorol 56:421-428

Kalnay E, Kanamitsu M, Kistler R, Collins W, Deaven D, Gandin L, Iredell M, Saha S, White G, Woollen J, Zhu Y, Leetmaa A, Reynolds R, Chelliah M, Ebisuzaki W, Higgins W, Janowiak J, Mo KC, Ropelewski C, Wang J, Jenne R, Joseph D (1996) The NCEP/NCAR 40-year reanalysis project B. Am Meteorol Soc 77: 437-470

Kažys J, Malūnavičiūtė I (2015) The evaluation of summer beaching conditions on the Baltic Sea coast using the UTCI index. Int J Clim Chang: Impacts Resp 7:41-59 
Kozłowska-Szczesna T, Krawczyk B, Kuchcik M, (2004) Wpływ środowiska atmosferycznego na zdrowie i samopoczucie człowieka. Monografie 4, IGiPZ PAN, Warszawa

Kyselý J (2008) A cautionary note on the use of nonparametric bootstrap for estimating uncertainties in extreme value models. J Appl Meteorol Climatol 47:3236-3251

Lindner K (2011) Assessment of sensible climate in Warsaw using UTCI. Pr Studia Geogr 47:85-291

Lindner-Cendrowska K (2013) Assessment of bioclimatic conditions in cities for tourism and recreational purposes (a Warsaw case study). Geogr Pol 86:55-66

Matzarakis A, Muthers S, Rutz F (2014) Application and Comparison of UTCI and PET in temperate climate conditions. Finisterra 49(98): 21-31

Mayer H, Höppe P (1987) Thermal comfort of man in different urban environments. Ther Appl Climatol 38(1):43-49

Mąkosza A (2013) Bioclimatic conditions of the Lubuskie Voivodeship. Geogr Pol 86:37-46

Milewski P (2013) Application of the UTCI to the local bioclimate of Poland's Ziemia Kłodzka region. Geogr Pol 86:47-54

Nidzgorska-Lencewicz J (2015) Variability of human-biometeorological conditions in Gdańsk. Pol J Environ Stud 24:215-226

Nidzgorska-Lencewicz J, Mąkosza J (2013) Assessment of bioclimatic conditions within the area of Szczecin. Agglomaration Meteorol Z 22:615-626

Novak M (2013) Use of the UTCI in the Czech Republic. Geogr Pol 86: 21-28

Nowosad M, Rodzik B, Wereski S, Dobek M (2013) The UTCI index in Lesko and Lublin and its circulation determinants. Geogr Pol 86:29 36

Original S code by Richard A Becker, Allan R Wilks R version by Ray Brownrigg Enhancements by Thomas P Minka and Alex Deckmyn (2016) Maps: draw geographical maps R package version 311. http://CRAN.R-project.org/package=maps
Park S, Tuller SE, Jo M (2014) Application of universal thermal climate index (UTCI) for microclimatic analysis in urban thermal environments. Landsc Urban Plan 125:146-155

Pierce D (2013): ncdf4: interface to Unidata netCDF (version 4 or earlier) format data files - $\mathrm{R}$ package ver 110

R Core Team (2015): R: a language and environment for statistical computing - R Foundation for Statistical Computing, Vienna, Austria, www.R-project.org

Rutty M, Scott D (2014) Thermal range of coastal tourism resort microclimates tourism geographies. Int J Tour Space, Place Environ 16: 346-363

Świątek M (2014) Seasonal variability of climatic conditions for tourism and recreation along the southern coast of the Baltic Sea. Bull Geogr Phys Geogr Ser 7:57-80

Urban A, Kyselý J (2014) Comparison of UTCI with other thermal indices in the assessment of heat and cold effects on cardiovascular mortality in the Czech Republic. Int J Environ Res Public Health 11(1):952-967

Ustrnul Z, Czekierda D, Wypych A (2010) Classifications of atmospheric circulation patterns: theory and applications. Phys Chem Earth Parts $\mathrm{A} / \mathrm{B} / \mathrm{C}$ 9-12:429-436

Ustrnul Z, Czekierda D (2002) Ekstremalne wartości temperatury powietrza w Polsce w drugiej połowie XX wieku na tle warunków cyrkulacyjnych (Extreme air temperature values in Poland in the second half of XX century according to different atmospheric circulation conditions). Wiad IMGW 25(46):3-22

Ward JH, Jr (1963) Hierarchical grouping to optimize an objective function. J Am Stat Assoc 58:236-244

Wibig J (2007) Fale ciepła i chłodu w środkowej Polsce na przykładzie Łodzi (Waves of Warmth and Coldness in Central Poland on the Example of Łódź) Acta Universitatis Lodziensis, Folia Geographica. Physica 8:27-61

Wilks DS (2006) Statistical methods in the atmospheric sciences, 2nd edn. Academic Press, London

Yarnal B (1993) Synoptic climatology in environmental analysis. Belhaven Press, London 